\title{
Oxidized Low-Density Lipoproteins Potentiate the Mitogenic Effect of 5-Hydroxytryptamine on Vascular Smooth Muscle Cells
}

\author{
Takuya WATAnABe, ${ }^{1}$ MD, Rajbabu PAKAlA,${ }^{2} \mathrm{PhD}$, Takashi KATAGIRI, ${ }^{1} \mathrm{MD}$, \\ and Claude R. BENEDICT, ${ }^{2} \mathrm{MD}$
}

\begin{abstract}
SUMMARY
Considerable attention has been focused on both highly oxidized low-density lipoprotein (ox-LDL) and mildly oxidized LDL (mox-LDL) as important risk factors for cardiovascular disease. Further, 5-hydroxytryptamine (5-HT) appears to play a crucial role in the development of atherosclerotic plaque. We assessed the interaction of oxidatively modified LDL and its major oxidative components, ie, hydrogen peroxide $\left(\mathrm{H}_{2} \mathrm{O}_{2}\right)$, lysophosphatidylcholine (LPC), and 4-hydroxy-2-nonenal (HNE) with 5-HT on DNA synthesis in vascular smooth muscle cells (VSMCs). Growth-arrested rabbit VSMCs were incubated in serum-free medium with native LDL, mox-LDL, ox-LDL (all $50 \mathrm{ng} / \mathrm{mL}$ ), $\mathrm{H}_{2} \mathrm{O}_{2}(0.5$ $\mu \mathrm{M})$, LPC $(1 \mu \mathrm{M})$, or HNE $(0.1 \mu \mathrm{M})$ for 24 hours followed by 5-HT $(5 \mu \mathrm{M})$ for another 24 hours. DNA synthesis in VSMCs was measured by $\left[{ }^{3} \mathrm{H}\right]$ thymidine incorporation. Significant effects on $\left[{ }^{3} \mathrm{H}\right]$ thymidine incorporation were observed in VSMCs incubated with mox-LDL (129\%), ox-LDL (129\%), $\mathrm{H}_{2} \mathrm{O}_{2}$ (119\%), LPC (115\%), HNE (127\%), or 5-HT $(183 \%)$ in contrast with native LDL $(113 \%)$. The mitogenic effect of 5-HT was potentiated by mox-LDL, ox-LDL, $\mathrm{H}_{2} \mathrm{O}_{2}$, LPC, or HNE (183 to $365 \%, 274 \%, 304 \%, 339 \%$, or $273 \%$, respectively) but not by native LDL $(240 \%)$. The mitogen-activated protein kinase (MAPK) kinase inhibitor PD98059 $(10 \mu \mathrm{M})$ signficantly inhibited the mitogenic effect of 5-HT but did not influence the effects of mox-LDL, ox-LDL, $\mathrm{H}_{2} \mathrm{O}_{2}$, LPC, or HNE. The intracellular antioxidant $\mathrm{N}$-acetylcysteine $(400 \mu \mathrm{M})$ siginificantly inhibited the mitogenic effects of mox-LDL, ox-LDL, $\mathrm{H}_{2} \mathrm{O}_{2}$, LPC, and HNE but not that of 5-HT. Our results suggest that mox-LDL, ox-LDL, and their major components $\mathrm{H}_{2} \mathrm{O}_{2}$, LPC, and HNE act synergistically with 5-HT in inducing VSMC DNA synthesis via MAPK and redox-sensitive pathways, contributing to the development of atherosclerotic plaque. (Jpn Heart J 2002; 43: 35-42)
\end{abstract}

Key words: 5-Hydroxytryptamine, Atherosclerotic plaque, Lipoproteins, Signal transduction, Vascular smooth muscle cell

From ${ }^{1}$ the Third Department of Internal Medicine, Showa University School of Medicine, Tokyo, Japan, and ${ }^{2}$ Department of Internal Medicine, Division of Cardiology, University of Texas-Houston Health Science Center, Houston, Texas, USA.

Address for correspondence: Takuya Watanabe, MD, Chief of Internal Medicine, Showa University Karasuyama Hospital, 6-11-11 Kita-karasuyama, Setagaya-ku, Tokyo 157-8577, Japan.

Received for publication September 6, 2001.

Revised and accepted September 17, 2001. 
LOW-density lipoprotein (LDL), a major carrier of cholesterol, is one of the most important risk factors for cardiovascular disease. Therefore, the effect of LDL on vascular smooth muscle cells (VSMCs) has been under intense investigation. An oxidative modification of LDL increases its atherogenic potential since oxidatively modified LDL has been shown to be more mitogenic for VSMCs and monocytes. ${ }^{1)} \mathrm{LDL}$ oxidation is a progressive process leading initially to the formation of mildly oxidized LDL (mox-LDL; defined by low content of lipid peroxidation derivatives), and later to highly oxidized LDL (ox-LDL; characterized by high levels of lipid peroxidation derivatives and severe apoB alterations). ${ }^{2)}$ Ox-LDL exhibits a wide variety of biological effects potentially involved in atherogenesis, such as alterations of (1) lipid metabolism (leading to foam cell formation), (2) gene expression (of adhesion molecules, heat shock proteins, cytokines, growth factors, coagulation proteins), (3) cell migration, motility, and contractility, (4) cell viability, (5) local immune response, and (6) vasomotor tone. ${ }^{3)}$ Ox-LDL is characterized by altered chemical and physical properties, including elevated levels of lipid hydroperoxides, oxidized sterols, lysophosphatidylcholine (LPC), degradation fragments of apo B-100, and increased electrophoretic mobility. ${ }^{3)}$ It has also been demonstrated that 4hydroxy-2-nonenal (HNE), a major lipid peroxidation product of ox-LDL, and LPC and reactive oxygen species (ROS), two active ingredients of mox-LDL, stimulate VSMC growth., ${ }^{4,5)}$

We and others have demonstrated that mox-LDL and ox-LDL potentiate the contractile and mitogenic effects of 5-hydroxytryptamine (5-HT), also known as serotonin, in VSMCs via the 5- $\mathrm{HT}_{2 \mathrm{~A}}$ receptor coupled with G protein. ${ }^{67)}$ However, the downstream signal pathways have yet remained unclear.

The aim of this study was to examine the mechanism responsible for synergistic interaction of mox-LDL, ox-LDL, or their oxidative components such as hydrogen peroxide $\left(\mathrm{H}_{2} \mathrm{O}_{2}\right.$, a donor of ROS), LPC, and HNE with 5-HT on DNA synthesis in cultured VSMCs.

\section{Materials ANd Methods}

Materials: Human LDL, LPC, HNE, PD98059, and N-acetylcysteine (NAC) were purchased from Sigma Chemical Co. (St Louis, MO, USA) and $\mathrm{H}_{2} \mathrm{O}_{2}$ was obtained from Fisher Scientific (Fair Lawn, NJ, USA). $\left.{ }^{3} \mathrm{H}\right]$ Thymidine (specific activity, $20 \mathrm{Ci} / \mathrm{mol}$ ) was obtained from DuPont NEN Research Products (Boston, MA, USA).

LDL oxidation: Mox-LDL and ox-LDL were prepared as described previously. ${ }^{5)}$ Lipoprotein concentrations are expressed as protein concentrations. Even at a concentration of $10 \mathrm{mg} / \mathrm{mL}$, native LDL (n-LDL) showed no development of 
thiobarbituric acid-reactive substances (TBARS), whereas mox-LDL showed a slight increase in TBARS formation ( 2 to $4 \mathrm{nmol} / \mathrm{mg}$ protein) with no change in the electrophoretic mobility. In contrast, ox-LDL showed a significant increase in TBARS formation ( $35 \mathrm{nmol} / \mathrm{mg}$ protein) and an increase in the electrophoretic mobility.

Cell culture: VSMCs were isolated from the thoracic aortas of male New Zealand White rabbits (body weight 2.5 to $3 \mathrm{~kg}, n=30$ ) by the explant method and were cultured in a humidified atmosphere $\left(5 \% \mathrm{CO}_{2} / 95 \%\right.$ air $)$ at $37^{\circ} \mathrm{C}$. 4,5$)$ After 3 to 4 weeks, the tissue blocks were removed and the migrated VSMCs were cultured, followed by subculture using trypsinization. The identity of the VSMCs was confirmed by morphological examination and by staining for $\alpha$-actin.

DNA synthesis: DNA synthesis was examined by measurement of $\left[{ }^{3} \mathrm{H}\right]$ thymidine incorporation into the cellular DNA., ${ }^{4,5}$ After synchronization or growth arrest of VSMCs in passage 1 to 2, the medium was replaced with Dulbecco's modified Eagle's medium containing $500 \mu \mathrm{g} / \mathrm{mL}$ bovine serum albumin, $10 \mu \mathrm{g} / \mathrm{mL}$ bovine insulin, $20 \mu \mathrm{g} / \mathrm{mL}$ human transferrin, $25 \mathrm{ng} / \mathrm{mL}$ selenium, and $100 \mu \mathrm{M}$ pargyline. Following this, two different experiments were performed, as outlined below.

Experiment 1: VSMCs were incubated with indicated concentrations of nLDL, mox-LDL, ox-LDL, $\mathrm{H}_{2} \mathrm{O}_{2}$, LPC, or HNE for 24 hours followed by 5-HT ( 5 $\mu \mathrm{M})$ for another 24 hours.

Experiment 2: VSMCs were incubated with the same concentrations of mox-LDL, ox-LDL, $\mathrm{H}_{2} \mathrm{O}_{2}$, LPC, or HNE along with the mitogen-activated protein kinase (MAPK) kinase inhibitor PD98059 $(10 \mu \mathrm{M})$ or the intracellular antioxidant NAC $(400 \mu \mathrm{M})$ for 24 hours followed by 5 -HT $(5 \mu \mathrm{M})$ for another 24 hours.

For all experiments, VSMCs were exposed to $\left[{ }^{3} \mathrm{H}\right]$ thymidine at a concentration of $1 \mu \mathrm{Ci} /$ plate for the last 5 hours in the 24-hour incubation with $5-\mathrm{HT}$. $\left[{ }^{3} \mathrm{H}\right]$ Thymidine incorporated into cellular DNA was measured with a scintillation counter (Packard Instrument Co., Downers Grove, IL, USA). All the experiments were performed in quadruplicate and each experiment was repeated at least three times.

Statistical analysis: Data are expressed as mean \pm SEM. Multiple comparisons were evaluated by ANOVA followed by the Bonferroni test. A value of $p<0.05$ was considered statistically significant.

\section{RESULTS}

Effects of n-LDL, mox-LDL, ox-LDL, $\mathrm{H}_{2} \mathrm{O}_{2}$, LPC, or HNE with 5-HT on VSMC DNA synthesis: Our previous studies have shown the effects of n-LDL, moxLDL, ox-LDL, $\mathrm{H}_{2} \mathrm{O}_{2}$, LPC, HNE, 5-HT on $\left[{ }^{3} \mathrm{H}\right]$ thymidine incorporation into 
DNA in rabbit aortic VSMCs. ${ }^{4,5)} \mathrm{N}-\mathrm{LDL}$ at the concentrations tested did not have any significant effect on $\left[{ }^{3} \mathrm{H}\right]$ thymidine incorporation. In contrast, mox-LDL, oxLDL, $\mathrm{H}_{2} \mathrm{O}_{2}$, LPC, HNE, or 5-HT stimulated [ $\left.{ }^{3} \mathrm{H}\right]$ thymidine incorporation in a dose-dependent manner. Mox-LDL and ox-LDL had a maximal effect at a concentration of $5 \mu \mathrm{g} / \mathrm{mL}(211 \pm 25 \%, 154 \pm 2 \%), \mathrm{H}_{2} \mathrm{O}_{2}$ at $5 \mu \mathrm{M}(177 \pm 7 \%), \mathrm{LPC}$ at 15 $\mu \mathrm{M}(156 \pm 8 \%), \mathrm{HNE}$ at $1 \mu \mathrm{M}(143 \pm 8 \%)$, and 5 -HT at $50 \mu \mathrm{M}(211+14 \%)$. Our previous studies also have shown a significant interaction in inducing VSMC proliferation when low concentrations of two or more compounds were added together. ${ }^{4,5,7,8)}$ Therefore, in the present study, we evaluated the interaction between low concentrations of n-LDL, mox-LDL, ox-LDL (all $50 \mathrm{ng} / \mathrm{mL}$ ), $\mathrm{H}_{2} \mathrm{O}_{2}$ $(0.5 \mu \mathrm{M})$, LPC $(1 \mu \mathrm{M})$, or HNE $(0.1 \mu \mathrm{M})$ and 5-HT $(5 \mu \mathrm{M})$ (Figure 1). MoxLDL, ox-LDL, $\mathrm{H}_{2} \mathrm{O}_{2}$, LPC, and HNE had a slight but significant effect on $\left[{ }^{3} \mathrm{H}\right]$ thymidine incorporation. Further, they potentiated the effect of 5-HT on $\left[{ }^{3} \mathrm{H}\right]$ thymidine incorporation $(183 \pm 2 \%$ to $365 \pm 14 \%, 274 \pm 12 \%, 304 \pm 12 \%$, $339 \pm 12 \%$, or $273 \pm 28 \%, p<0.0001$; respectively). In contrast, the effect of $n-L D L$

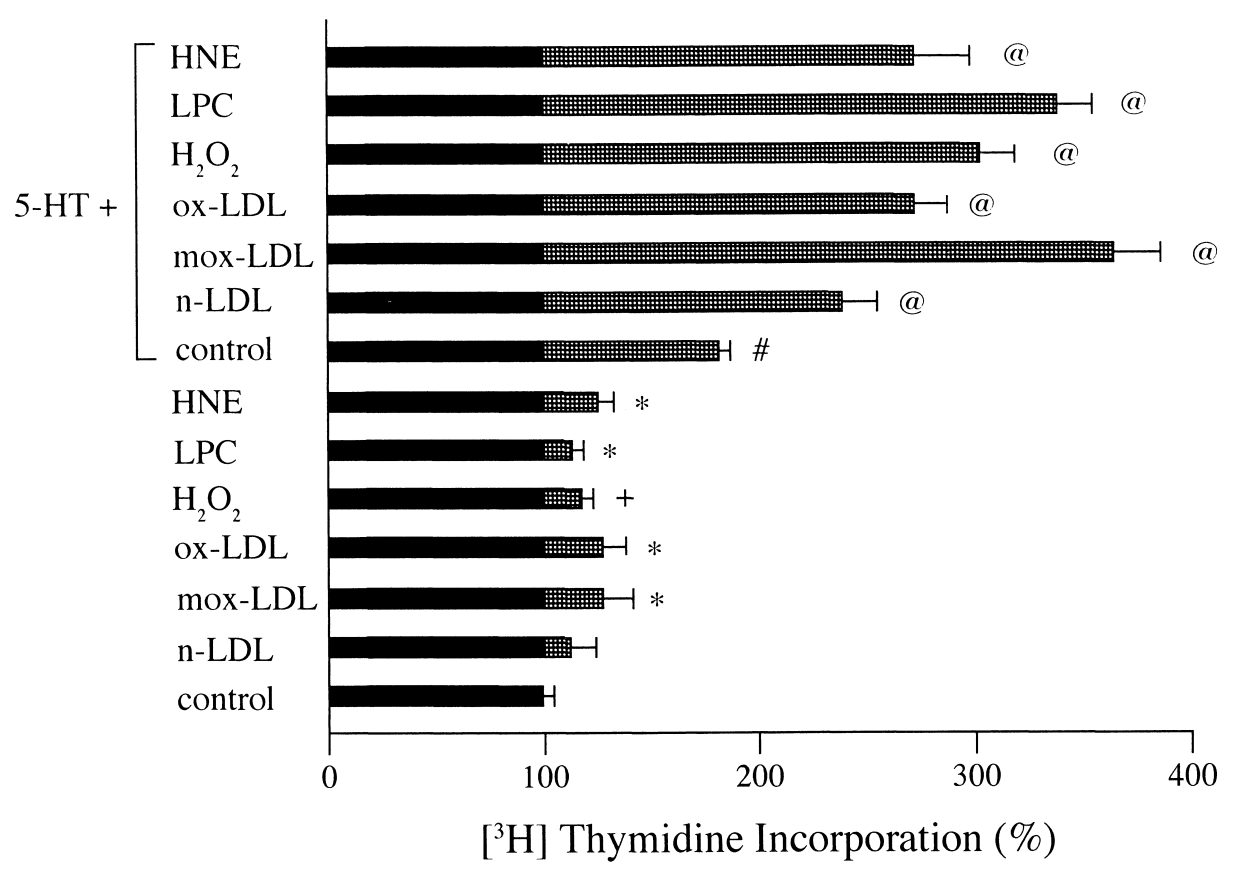

Figure 1. Interaction of n-LDL, mox-LDL, ox-LDL, $\mathrm{H}_{2} \mathrm{O}_{2}$, LPC, or HNE with 5-HT in inducing VSMC DNA synthesis. Growth-arrested VSMCs were stimulated with n-LDL, mox-LDL, ox-LDL (all $50 \mathrm{ng} / \mathrm{mL}$ ), $\mathrm{H}_{2} \mathrm{O}_{2}(0.5 \mu \mathrm{M}), \mathrm{LPC}(1 \mu \mathrm{M})$, or HNE $(0.1 \mu \mathrm{M})$ for 24 hours followed by 5 -HT $(5 \mu \mathrm{M})$ for another 24 hours. The amount of [ $\left.{ }^{3} \mathrm{H}\right]$ thymidine incorporation into DNA was measured. Each value is expressed as mean \pm SEM of three separate experiments. The control value (240 \pm 11 cpm) is regarded as $100 \%{ }^{*} p<0.05,+p<0.01, \# p<0.0001$ vs the control; @ $p<0.0001$ vs 5-HT alone. 
with 5 -HT on $\left[{ }^{3} \mathrm{H}\right]$ thymidine incorporation was additive but not synergistic (240土13\%).

Effect of PD98059 or NAC on VSMC DNA synthesis: To examine whether the mitogenic effects of mox-LDL, ox-LDL, $\mathrm{H}_{2} \mathrm{O}_{2}$, LPC, HNE, or 5-HT are mediated by the MAPK pathway or the redox-sensitive pathway, we assessed the inhibitory effect of the MAPK kinase inhibitor PD98059 $(10 \mu \mathrm{M})$ or the intracellular antioxidant NAC $(400 \mu \mathrm{M})$ on the mox-LDL, ox-LDL (both $50 \mathrm{ng} / \mathrm{mL}), \mathrm{H}_{2} \mathrm{O}_{2}(0.5$ $\mu \mathrm{M})$, LPC $(1 \mu \mathrm{M}), \mathrm{HNE}(0.1 \mu \mathrm{M})$, or 5-HT $(5 \mu \mathrm{M})$-induced $\left[{ }^{3} \mathrm{H}\right]$ thymidine incorporation. PD98059 or NAC by themselves were without any significant effect on $\left[{ }^{3} \mathrm{H}\right]$ thymidine incorporation (Figure 2). However, PD98059 significantly inhibited the mitogenic effect of 5-HT $(p<0.001)$ without an influence on the effect of mox-LDL, ox-LDL, $\mathrm{H}_{2} \mathrm{O}_{2}$, LPC, or HNE. In contrast, NAC significantly inhib-

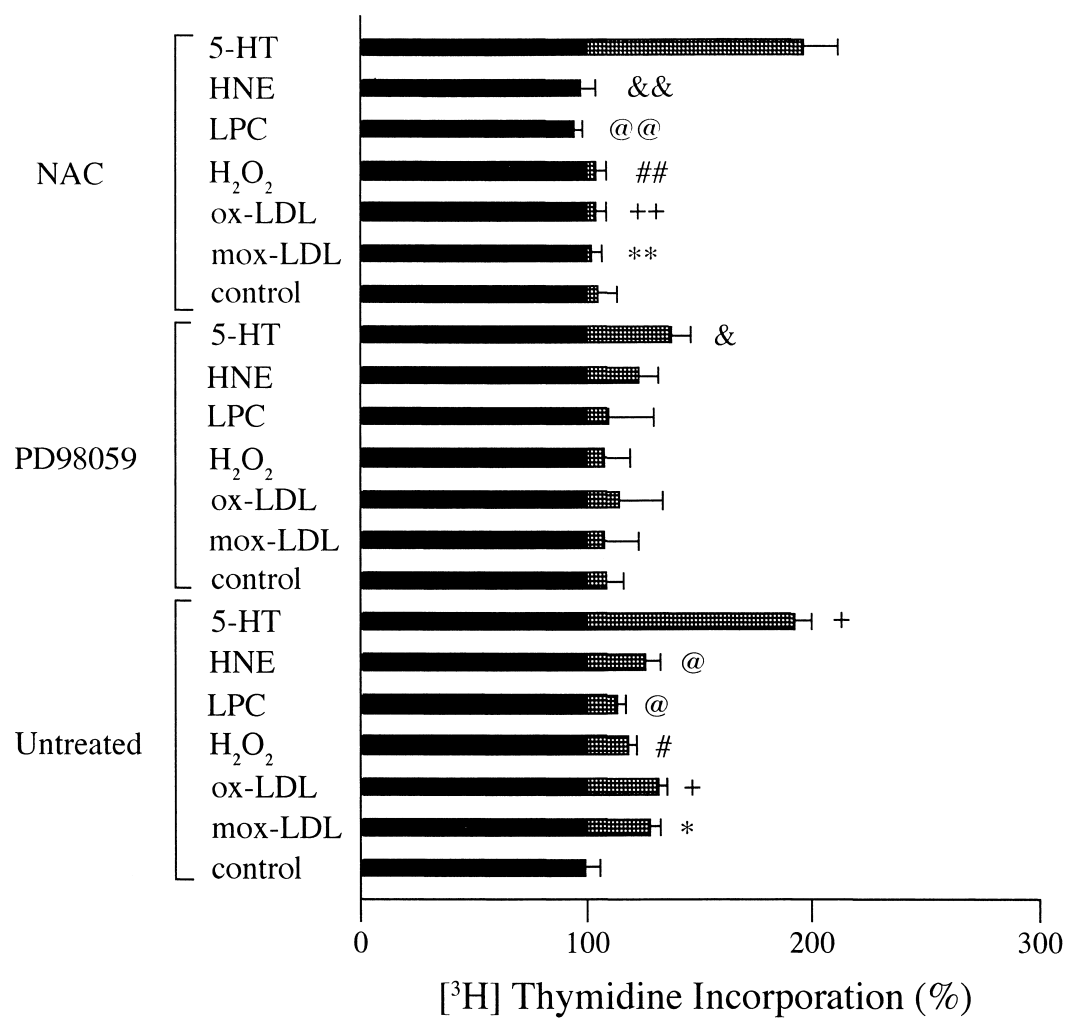

Figure 2. Effect of PD98059 and NAC on VSMC DNA synthesis. Growth-arrested VSMCs were stimulated with moxLDL, ox-LDL (both $50 \mathrm{ng} / \mathrm{mL}), \mathrm{H}_{2} \mathrm{O}_{2}(0.5 \mu \mathrm{M})$, LPC $(1 \mu \mathrm{M})$, HNE $(0.1 \mu \mathrm{M})$, or 5-HT $(5 \mu \mathrm{M})$ in the presence of PD98059 $(10 \mu \mathrm{M})$ or NAC $(400 \mu \mathrm{M})$, and the amount of $\left[{ }^{3} \mathrm{H}\right]$ thymidine incorporation into DNA was measured. Each value is expressed as mean \pm SEM of three separate experiments. The control value $(222 \pm 10 \mathrm{cpm})$ is regarded as $100 \%$. ${ }^{*} p<0.0005$, $+p<0.0001, \# p<0.01, @ p<0.05$ vs untreated control; $\& \mathrm{p}<0.001$ vs untreated 5 -HT; ${ }^{*} p<<0.0001$ vs untreated mox-LDL, $++p<0.0001$ vs untreated ox-LDL; \#\# $<0.05$ vs untreated $\mathrm{H}_{2} \mathrm{O}_{2}$;@@ $p<0.0001$ vs untreated LPC; \& \& $p<0.005$ vs untreated HNE. 
ited the mitogenic effect of mox-LDL, ox-LDL, $\mathrm{H}_{2} \mathrm{O}_{2}$, LPC, or HNE (at least $p<0.05$ ) but not that of 5-HT.

\section{DISCUSSION}

In the present study, we show that mox-LDL and ox-LDL and their oxidative components $\mathrm{LPC}, \mathrm{H}_{2} \mathrm{O}_{2}$, and $\mathrm{HNE}$ have a mitogenic effect and further potentiate the mitogenic effect of 5-HT on VSMCs. The MAPK inhibitor PD98059 significantly inhibited the mitogenic effect of 5-HT only. In contrast, NAC significantly inhibited the mitogenic effect of mox-LDL, ox-LDL, $\mathrm{H}_{2} \mathrm{O}_{2}, \mathrm{LPC}$, and HNE, but not that of 5-HT.

It is generally accepted that oxidatively modified LDL plays an important role in the development of atherosclerosis by inducing VSMC proliferation. ${ }^{1,3}$ LDL oxidation is a progressive process initially leading to the formation of moxLDL and later to ox-LDL. The extent of changes in LDL particles induced by oxidation depends on the pro-oxidant conditions, and the length of time the particles are exposed to these conditions. Under physiological conditions which include the presence of various antioxidants such as $\alpha$-tocopherol and $\beta$-carotene in the plasma, complete oxidation of LDL may not be feasible. A more likely scenario is the partial oxidation of LDL with the production of mox-LDL, which was shown to act more synergistically with 5-HT than ox-LDL and n-LDL in this study. Thus, an interaction between mox-LDL and other mitogens for VSMCs may play an important role in the development of atherosclerosis.

The increased atherogenic effect of mox-LDL or ox-LDL is attributed to the chemical changes brought about by the oxidation processes to the components of LDL, namely, generation of ROS and conversion of phosphatidylcholine to LPC. ${ }^{9)}$ During the early stages of oxidation, there is a significant accumulation of peroxides and presumably also other ROS, whereas the LPC levels are still relatively low. After 24 hours of oxidative stress, LDL contains large amounts of LPC but only small amounts of ROS. ${ }^{9)}$ Extensive oxidation is associated with the formation of HNE. ${ }^{4)}$ Thus mox-LDL may contain a moderate level of LPC and ROS and a minimal concentration of HNE, whereas ox-LDL may contain high concentrations of LPC and HNE. Several studies from our laboratory and others have shown that mox-LDL and ox-LDL and their oxidative components, ie, LPC, ROS, and HNE induce VSMC proliferation. ${ }^{4,5,9-14)}$ Ox-LDL, ROS, LPC, and HNE activate the redox-sensitive pathway as well as the extracellular signal-regulated kinase (ERK) 1/2 MAPK pathway. ${ }^{13-20)}$ In the present study, mox-LDL, ox-LDL, $\mathrm{H}_{2} \mathrm{O}_{2}$, LPC, or HNE-induced DNA synthesis was significantly reduced by the intracellular antioxidant NAC but not by the MAPK kinase inhibitor PD98059, 
suggesting that the mitogenic effect of mox-LDL, ox-LDL, $\mathrm{H}_{2} \mathrm{O}_{2}$, LPC, or HNE may be mediated predominantly via the redox-sensitive pathway.

Serotonergic receptors have been subdivided into ligand-gated receptors and pertussis toxin-sensitive $G$ protein-coupled receptors. ${ }^{7,21)}$ The latter class is divided further into three subclasses according to the second messenger pathways to which the receptors are coupled. ${ }^{21)}$ The mitogenic effect of 5-HT on rabbit aortic VSMCs is mediated predominantly by $5-\mathrm{HT}_{2}$ receptors that are coupled to the activation of phospholipase C. ${ }^{21)}$ Previous studies have shown that the mitogenic effect of 5-HT on aortic VSMCs is mediated via the 5-HT $2 \mathrm{~A}$ receptor coupled with pertussis toxin-sensitive $G$ protein and is linked to an intracellular signaling pathway that involves c-Src protein tyrosine kinase and also protein kinase $\mathrm{C}$ and the ERK1/2 MAPK. ${ }^{7,21-24)}$ In the present study, the mitogenic effect of 5-HT was significantly inhibited by the MAPK kinase inhibitor PD98059 but not by the intracellular antioxidant NAC. These findings suggest that the combined stimulation of the MAPK pathway by 5-HT and the redox-sensitive pathway by moxLDL, ox-LDL, $\mathrm{H}_{2} \mathrm{O}_{2}$, LPC, or HNE may induce these synergistic interactions.

In conclusion, our results suggest that mox-LDL and ox-LDL and their oxidative components LPC, $\mathrm{H}_{2} \mathrm{O}_{2}$ (a donor of ROS), and HNE may act synergistically with 5-HT in inducing VSMC proliferation via MAPK and redox-sensitive pathways, contributing to the development of atherosclerotic plaque.

\section{REFERENCES}

1. Steinberg D. A critical look at the evidence for the oxidation of LDL in atherogenesis. Atherosclerosis 1997; 131(Suppl) : S5-7.

2. Esterbauer H, Dieber-Rotheneder M, Waeg G, Striegl G, Jurgens G. Biochemical, structural and functional properties of oxidized low density lipoprotein. Chem Res Toxicol 1990; 3: 77-92.

3. Steinberg D. Low density lipoprotein oxidation and its pathobiological significance. J Biol Chem 1997; 272: 20963-6.

4. Watanabe T, Pakala R, Katagiri T, Benedict CR. Lipid peroxidation product 4-hydroxy-2-nonenal acts synergistically with serotonin in inducing vascular smooth muscle cell proliferation. Atherosclerosis 2001; 155: 37 44.

5. Watanabe T, Pakala R, Katagiri T, Benedict CR. Mildly oxidized low-density lipoprotein acts synergistically with angiotensin II in inducing vascular smooth muscle cell proliferation. J Hypertens 2001; 19 :1065-73.

6. Cox DA, Cohen ML. Selective enhancement of 5-hydroxytryptamine-induced contraction of porcine coronary artery by oxidized low-density lipoprotein. J Pharmacol Exp Ther 1992; 261: 856-62.

7. Koba S, Pakala R, Watanabe T, Katagiri T, Benedict CR. Vascular smooth muscle proliferation: synergistic interaction between serotonin and low density lipoproteins. J Am Coll Cardiol 1999; 34: 1644-51.

8. Watanabe T, Pakala R, Katagiri T, Benedict CR. Angiotensin II and serotonin potentiate endothelin-1-induced vascular smooth muscle cell proliferation. J Hypertens 2001; 19: 731-9.

9. Stiko A, Regnstrom J, Shah PK, Cercek B, Nilsson J. Active oxygen species and lysophosphatidylcholine are involved in oxidized low density lipoprotein activation of smooth muscle cell DNA synthesis. Arterioscler Thromb Vasc Biol 1996; 16: 194-200.

10. Chai YC, Howe PH, DiCorleto PE, Chisolm GM. Oxidized low density lipoprotein and lysophosphatidylcholine stimulate cell cycle entry in vascular smooth muscle cells. J Biol Chem 1996; 271: 17791-7. 
11. Rao GN, Berk BC. Active oxygen species stimulate vascular smooth muscle cell growth and proto-oncogene expression. Circ Res 1992; 70: 593-9.

12. Chen $\mathrm{Y}$, Morimoto S, Kitano S, et al. Lysophosphatidylcholine causes $\mathrm{Ca}^{2+}$ influx, enhanced DNA synthesis and cytotoxicity in cultured vascular smooth muscle cells. Atherosclerosis 1995; 112: 69-76.

13. Ruef J, Rao GN, Li F, et al. Induction of rat aortic smooth muscle cell growth by the lipid peroxidation product 4-hydroxy-2-nonenal. Circulation 1998; 97: 1071-8.

14. Watanabe T, Pakala R, Katagiri T, Benedict CR. Lysophosphatidylcholine is a major contributor to the synergistic effect of mildly oxidized LDL with endothelin-1 on vascular smooth muscle cell proliferation. J Cardiovasc Pharmacol 2002; 39: in press.

15. Yokoyama M, Inoue N, Kawashima S. Role of the vascular NADH/NADPH oxidase system in atherosclerosis. Ann N Y Acad Sci 2000; 902: 241-8.

16. Kusuhara M, Chait A, Cader A, Berk BC. Oxidized LDL stimulates mitogen-activated protein kinases in smooth muscle cells and macrophages. Arterioscler Thromb Vasc Biol 1997; 17: 141-8.

17. Yang CM, Chien CS, Hsiao LD, et al. Mitogenic effect of oxidized low-density lipoprotein on vascular smooth muscle cells mediated by activation of Ras/Raf/MEK/MAPK pathway. Br J Pharmacol 2001; 132: 1531-41.

18. Baas AS, Berk BC. Differential activation of mitogen-activated protein kinases by $\mathrm{H}_{2} \mathrm{O}_{2}$ and $\mathrm{O}_{2}$ - in vascular smooth muscle cells. Circ Res 1995; 77: 29-36.

19. Yamakawa T, Eguchi S, Yamakawa Y, et al. Lysophosphatidylcholine stimulates MAP kinase activity in rat vascular smooth muscle cells. Hypertension 1998; 31: 248-53.

20. Ozaki H, Ishii K, Arai H, Kume N, Kita T. Lysophosphatidylcholine activates mitogen-activated protein kinases by a tyrosine kinase-dependent pathway in bovine aortic endothelial cells. Atherosclerosis 1999; 143: 261-6.

21. Pakala R, Willerson JT, Benedict CR. Effect of serotonin, thromboxane $\mathrm{A}_{2}$, and specific receptor antagonists on vascular smooth muscle cell proliferation. Circulation 1997; 96: 2280-6.

22. Hershenson MB, Chao TSO, Abe MK, et al. Histamine antagonizes serotonin and growth factor-induced mitogen-activated protein kinase activation in bovine tracheal smooth muscle cells. J Biol Chem 1995; 270: 1990813.

23. Watts SW. 5-Hydroxytryptamine-induced potentiation of endothelin-1- and norepinephrine-induced contraction is mitogenic-activated protein kinase pathway dependent. Hypertension 2000; 35: 244-8.

24. Banes A, Florian JA, Watta SW. Mechanisms of 5-hydroxytryptamine 2 A receptor activation of the mitogenactivated protein kinase pathway in vascular smooth muscle. J Pharmacol Exp Ther 1999; 291: 1179-87. 